\title{
Efektifitas Ekuitas Merek Berbasis Pelanggan pada Pengguna e-Ritel
}

\author{
Intan Permata Dewi \\ Universitas Padjajaran, Bandung, Indonesia \\ intan19015@mail.unpad.ac.id
}

\begin{abstract}
Customer based brand equity has recently emerged in both academic literature and practitioner discussions. The number of ecommerce that began to be established into consideration for every consumer to determine where they will shop online. In order to reduce the potential for customers to choose other e-commerce, companies need to increase customer-based brand equity. This research was conducted at one e retail in Indonesia through an online survey. Measurement of customer based brand equity uses dimensions 1) Emotional connection, 2) Online Experience, 3) Responsive Service Nature, 4) Trust, and 5) Fulfillment. The method used was an explanatory survey with 200 Tabachnick and Fidell sample techniques. The data analysis technique used is structural equation modeling (SEM) with the AMOS 22.0 for Windows program. The findings of this study indicate that the dimension of responsive service nature as a whole has the highest value, while for the dimension that has the lowest value is trust
\end{abstract}

Keyword : Customer Based Brand Equity; Brand Equity; e-Retail; Fashion Retail; Market Place

Abstrak - Ekuitas merek berbasis pelanggan baru-baru ini muncul baik dalam literatur akademik dan diskusi praktisi. Jumlah e-commerce yang terus bertambah menjadi pertimbangan bagi setiap konsumen untuk menentukan di mana mereka akan berbelanja online. Untuk mengurangi potensi pelanggan memilih e-commerce lain, perusahaan perlu meningkatkan ekuitas merek berbasis pelanggan. Penelitian ini dilakukan di salah satu e retail di Indonesia melalui survei online. Pengukuran ekuitas merek berbasis pelanggan menggunakan dimensi 1) Emotional connection, 2) Online Experience, 3) Responsive Service Nature, 4) Trust, and 5) Fulfillment. Metode yang digunakan adalah explanatory survei dengan 200 responden dan teknik perhitungan sampel dari Tabachnick dan Fidell. Teknik analisis data yang digunakan adalah pemodelan persamaan struktural (SEM) dengan program AMOS 22.0 for Windows. Temuan penelitian ini menunjukkan bahwa dimensi sifat Responsive Service Nature secara keseluruhan memiliki nilai tertinggi, sedangkan untuk dimensi yang memiliki nilai terendah adalah Trust.

Kata Kunci : Ekuitas Merek Berbasis Pelanggan; Ekuitas Merek; e-Ritel; Ritel Fesyen; Market Place

\section{PENDAHULUAN}

Merek telah menjadi salah satu bidang utama yang menjadi perhatian peneliti praktis sejak abad pertengahan hingga beberapa dekade terakhir, merek menjadi salah satu alat pemasaran yang sangat kuat [9]. Merek merupakan salah satu aset tidak berwujud yang paling berharga dari suatu perusahaan, pesaing dapat meniru proses manufaktur dan desain dari produk akan tetapi tidak akan dapat meniru nilai dari suatu merek [12]. Membangun merek dianggap sebagai cara terbaik untuk melakukan bisnis pada semua perusahaan karena banyak perubahan konstan dalam lingkungan pemasaran [5].

Nilai sebuah merek dapat diperkirakan melalui ekuitasnya [9]. Membangun ekuitas merek dianggap sebagai bagian penting dalam mengembangkan sebuah perusahaan karena pemasar bisa mendapatkan keunggulan kompetitif melalui merek yang kuat [25].

Copyright ( 2020 BIEJ: Business Innovation \& Entrepreneurship Journal e-ISSN : 2684-8945
Secara khusus keterikatan antara sebuah merek dengan perusahaan dapat dilihat dari dua perspektif yang berbeda yaitu dari segi ekuitas merek berbasis keuangan dan ekuitas merek berbasis konsumen [16]. Ekuitas merek berbasis keuangan berfokus pada nilai keuangan pada bisnis yang dijalankan dan dapat dilihat sebagai hasil dari respon konsumen untuk nama merek, sedangkan ekuitas merek berbasis pelanggan didasarkan pada persepsi pasar, yang mampu mengobati nilai perspektif pelanggan sebagai penggerak utama pangsa pasar dan profitabilitas [15].

Ekuitas merek berbasis pelanggan telah menjadi salah satu bidang utama yang menjadi perhatian setiap manajer dan peneliti pemasaran karena peran utama sebagai aset tidak berwujud perusahaan yang signifikan [6]. Setiap perusahaan harus memiliki kontrol dalam membangun ekuitas merek berbasis pelanggan dan harus berupaya meningkatkan ekuitas merek berbasis 
pelanggan yang sudah ada [14]. Pendekatan ekuitas merek berbasis pelanggan ini memberikan informasi lebih lanjut mengenai konsumen yang dapat dijadikan acuan pengambilan keputusan dalam keputusan manajerial strategi merek, pemasaran dan membangun merek [19].

Banyak penelitian telah membahas berbagai aspek dan manfaat dari ekuitas merek berbasis pelanggan seperti yang dilakukan [22] yang melakukan penelitian pada bidang farmasi dan kesehatan. [17] mengemukakan bahwa pada industri hospitality dan tourism technology ekuitas merek berbasis pelanggan masih menjadi sorotan untuk sebuah penelitian. [21] melakukan penelitian ekuitas merek berbasis pelanggan pada industri perbankan. [29] melakukan penelitian ekuitas merek berbasis pelanggan pada sosial media. Sementara [4] melakukan penelitian pada industri teknologi tepatnya di bidang e-commerce ritel.

Permasalahan terbesar bagi perusahaan di bidang e-commerce adalah kemungkinan bahwa konsumen tidak akan memahami nilai dari produk dan tidak mempercayai merek yang ditawarkan karena saluran distribusi berada pada virtual reallity sehingga konsumen tidak memiliki kontak perusahaan kecuali melalui internet, konsumen mungkin akan meragukan legitimasi dari perusahaan tersebut dan pada produk yang mereka jual [14]. Pemahaman mengenai merek merupakan salah satu faktor yang menentukan konsumen melakukan keputusan pembelian pada industri e-commerce karena konsumen akan cenderung membeli produk dengan merek yang sudah dikenal [10].

Penting bagi perusahaan e-commerce untuk membangun nilai ekuitas merek berbasis pelanggan karena perusahaan dapat membangun kesadaran konsumen akan merek dan dapat menciptakan kenangan dibenak konsumen [22] sehingga dengan kepercayaan konsumen akan merek perusahaan memperoleh keunggulan kompetitif, perusahaan harus mengedepankan merek yang mereka miliki untuk terus membangun hubungan jangka panjang dengan pelanggan dalam hal ini sering disebut loyalitas pelanggan [8].

Pada perusahaan yang bergerak di bidang $e$ commerce dapat berhasil dan berkembang menjadi perusahaan besar dengan nilai merek yang tinggi dan mendapatkan lebih banyak pelanggan dan investor, karena biasanya konsumen atau investor akan lebih percaya membagi uang pada merek yang sudah terkenal atau terpercaya [24]. Perusahaan e-commerce semakin berkembang disemua bidang namun terpantau saat ini $e$ commerce dan online marketplace yang masih menguasai arus bisnis di industri teknologi [31].

Jumlah perusahaan digital terus mengalami peningkatan dan mencoba berkompetisi menjadikan bisnis startup e-commerce menjadi sangat kompetitif. Perusahaan perlu untuk membangun ekuitas merek berbasis pelanggan yang akan menjadi nilai tambah bagi pelanggan sehingga pelanggan ingin kembali untuk melakukan pembelian, bersedia membayar lebih serta meningkatkan citra perusahaan dan membuat orang lain percaya dengan merek atau produk tersebut [2].

Dampak dari rendahnya nilai ekuitas merek berbasis pelanggan dapat berpengaruh terhadap margin keuntungan, terhadap harga, dan loyalitas pelanggan [1]. Banyak manfaat dari pemeliharaan ekuitas merek berbasis pelanggan [11] sebaliknya manfaat akan menjadi ancaman baru jika ekuitas merek berbasis pelanggan tidak dipelihara, seperti akan terjadi penurunan pada persepsi mengenai kualitas produk, penurunan pada loyalitas pelanggan, menjadi rentan terhadap tindakan kompetitif pemasaran dan rentan terhadap krisis pemasaran, margin pendapatan akan menurun, konsumen tidak mudah menerima adanya elastisitas harga yang terjadi, para investor tidak akan mudah percaya untuk bekerja sama dan berinvestasi, komunikasi pemasaran akan menurun, sulit mendapatkan peluang perizinan serta sulit untuk memperluas merek.

Konsep ekuitas merek berbasis pelanggan terdapat dalam strategy brand management yang mengemukakan bahwa ekuitas merek berbasis pelanggan dipengaruhi oleh brand knowledge, brand extention, brand awareness, dan brand image [11] Beberapa faktor lain berdasarkan penelitian yang dapat mempengaruhi ekuitas merek berbasis pelanggan diantaranya sense experience, feel experience, think experience, act experience, dan related experience [17]. Country of origin merupakan faktor yang dapat membangun ekuitas merek berbasis pelanggan [20]. Faktor lain yang dapat mempengaruhi ekuitas merek berbasis pelanggan yaitu marketing communication [18].

Dengan melihat pesatnya pertumbuhan bisnis dengan platform digital penelitian, dapat diperhatikan bahwa menyelidiki pentingnya ekuitas merek dalam 
sudut pandang pelanggan sangat penting. Oleh karena itu, penelitian kami memberikan beberapa kontribusi utama. Pertama, untuk mengidentifikasi dan memeriksa pendorong utama proses CBBE. Kedua, secara teoritis dan manajemen, penelitian ini bertujuan untuk meningkatkan pemahaman kita tentang CBBE pada belanja virtual seperti e-commerce, yang dapat digunakan untuk mendefinisikan kembali strategi dan taktik yang terfokus pada pelanggan.

Pada bagian selanjutnya, pertama-tama kita paparkan latar belakang konseptual dan kembangkan hipotesis. Kemudian, kami memperkenalkan konteks penelitian dan menggambarkan metodologi penelitian. Selanjutnya, kami melaporkan analisis data dan hasilnya. Akhirnya, kami menarik implikasi dari hasil kami dan mempertimbangkan keterbatasan dan arah untuk studi masa depan

\section{KAJIAN PUSTAKA}

Ekuitas merek didefinisikan sebagai seperangkat aset dan kewajiban yang terkait dengan merek, termasuk nama dan simbolnya, yang dapat memberi dampak menguntungkan atau merugikan pada nilai-nilai yang timbul dari produk atau layanan [7]. Konsep ekuitas merek umumnya dilihat dari dua perspektif 1) perspektif organisasi dan 2) perspektif pelanggan dari perspektif organisasi, merek dianggap sebagai aset yang menekankan potensi keuntungan finansial merek untuk organisasi sedangkan perspektif pelanggan menyangkut pikiran, perasaan, persepsi, dan pengalaman pelanggan mengenai merek [16].

Pendekatan ekuitas merek berbasis pelanggan adalah perspektif dominan kerena jika sebuah merek tidak memiliki arti atau nilai bagi konsumen hal itu akhirnya tidak berarti bagi investor, produsen, atau pengecer ekuitas merek berbasis pelanggan terjadi saat konsumen mengenal merek tersebut dan memiliki beberapa asosiasi merek yang menarik, kuat dan unik dalam ingatan mereka [6]. Pendekatan dari perspektif konsumen dan mengenali kekuatan dari merek tentang apa yang konsumen lihat, baca, dengar, pelajari, pikirkan, dan rasakan terhadap merek setiap waktu atau dengan kata lain pengetahuan konsumen terhadap merek. Perbedaan pengetahuan merek pada konsumen dapat mempengaruhi respon konsumen terhadap merek tersebut [12].

Copyright ( 2020 BIEJ: Business Innovation \& Entrepreneurship Journal e-ISSN : 2684-8945
Ekuitas merek berbasis pelanggan adalah respon pelanggan yang membentuk ekuitas merek tercermin dalam persepsi, prefensi, dan perilaku yang berkaitan dengan semua aspek pemasaran merek misalnya, pilihan dari merek, mengingat poin copy dari iklan, respon untuk promosi penjualan, dan evaluasi dari perluasan merek yang diusulkan tergantung pada apa yang berada dalam pikiran dan hati konsumen [11]

Seperangkat aset dan kepercayaan merek yang berfokus secara ekslusif pada hubungan yang dimiliki pelanggan dengan merek (dari ketidak pedulian terhadap keterikatan, loyalitas, dan kemauan untuk membeli dan rebuy berbasis pada keyakinan superioritas dan membangkitkan emosi) adalah pengertian ekuitas merek berbasis pelanggan yang diungkapkan oleh [28]

Ekuitas merek berbasis pelanggan adalah seperangkat aset yang didasarkan pada premis bahwa merek berada pada benak konsumen sebagai sikap kognitif konsumen, itulah sebabnya disebut ekuitas merek berbasis pelanggan [13].

Pengertian mengenai ekuitas merek berbasis pelanggan juga diungkapkan oleh [3] dalam penelitiannya ekuitas merek berbasis pelanggan yaitu perbedaan pengaruh pengetahuan merek terhadap konsumen dan respon terhadap pemasaran merek. Sedangkan [27] medefinisikan bahwa ekuitas merek berbasis pelanggan adalah efek diferensial pengetahuan merek pada respon konsumen terhadap pemasaran merek.

Terdapat beberapa proses untuk menciptakan suatu ekuitas merek dari persepsi pelanggan menurut [11] yang disebut dengan brand pyramid. Terdapat enam building block dalam brand pyramid tersebut yang dapat dijadikan sebagai tahapan pencapaian dari ekuitas merek, yakni brand salience, brand performance, brand imagery, brand judgments, brand feelings, dan brand resonance. Penelitian yang dilakukan [20] mengungkapkan dimensi dari customer based brand equity yaitu 1) Brand awareness, 2) Brand association,3) Perceived quiality 4) Brand loyalty. Penelitian [4] mengungkapkan dimensi ekuitas merek berbasis pelanggan dalam industri e-ritel sebagai berikut: 1) Emotional connection, 2) Online Experience, 3) Responsive Service Nature, 4) Trust, dan 5) Fulfillment.

Konsumen yang memiliki pengalaman online (online experience) berarti pengguna mencoba merek secara real time yang pada akhirnya berdampak pada 
persepsi mereka terhadap merek itu sendiri. Sifat layanan responsif (responsive service nature) merupakan mekanisme pelayanan dalam mendukung online ritel/service (ORS) dan tingkat interaksi layanan pelangan yang difasilitasi oleh situs. Mengingat sifat tak berwujud dari internet, pembeli sering mencari isyarat eksternal yang akan memungkinkan mereka untuk mengurangi resiko yang dirasakan, di lingkungan online, resiko sebagian besar terkait dengan privasi data dan keamanan transaksional. Kepercayaan terhadap merek sangat penting disini, kepercayaan (trust) mengacu pada harapan percaya diri akan keandalan merek dan niat dalam melibatkan pada situasi beresiko. Dimensi terakhir pemenuhan pemesanan (fulfillment) selalu ada baik pada dunia maya maupun dunia nyata, dan menyediakan koneksi antara pengalaman online dan offline. Jadi, jika barang yang dikirim tidak sesuai dengan barang yang dipesan atau pengiriman tidak sesuai pada saat yang dijanjikan maka kritik dari pelanggan kemunkinan besar akan terjadi sehingga merusak ekuitas merek pada online ritel/servive (ORS).

Pengukuran yang dipakai dalam penelitian ini adalah dimensi yang digunakan oleh [4] yaitu 1) Emotional connection, 2) Online Experience, 3) Responsive Service Nature, 4) Trust, dan 5) Fulfillment

\section{METODE}

Pada pengujian hipotesis, peneliti menggunakan metode kuantitatif menggunakan survei kuesioner untuk mengukur persepsi konsumen melalui survei online.. Data yang digunakan dalam penelitian ini berdasarkan sumber pengambilannya melalui Data primer dan Data sekunder. dalam penelitian ini yang dijadikan populasi adalah visitorsalah satu $e$-commerce sebanyak 231.482.

Penentuan jumlah sampel dengan menggunakan simple random sampling. Adapun rumus yang digunakan untuk mengambil suatu sampel dari sebuah populasi ialah dengan menggunakan rumus [26] . Teknik yang digunakan dalam penelitian ini adalah teknik nonprobablity sampling yaitu purposive sampling. Pengambilan sampel dalam hal ini terbatas pada jenis orang tertentu yang dapat memberikan informasi yang diinginkan, entah karena mereka adalah satu-satunya yang memilikinya, atau memenuhi beberapa kriteria yang ditentukan oleh peneliti [23]. Sampel yang didapatkan sebesar 200 responden.

Copyright ( 2020 BIEJ: Business Innovation \& Entrepreneurship Journal e-ISSN : 2684-8945
Dalam pemprosesan data penelitian menggunakan teknologi AMOS untuk analisis data multivariate yang disebut dengan structural equation modelling ukuran variabel ekuitas merek berbasis pelanggan yang digunakan meliputi emotional connection, online experience, responsive service nature, trust dan fulfillment.

\section{HASIL DAN PEMBAHASAN}

Mengukur variable laten ekuitas merek berbasis pelanggan, online experience merupakan indikator yang paling valid dengan nilai standardized loading estimate 0,958 dan Trust menunjukan validitas paling kecil nilai standardized loading estimate sebesar 0.797. Nilai tertinggi dan terendah dimensi tersebut menunjukan nilai standardized loading estimate $>0.5$ yang menunjukan bahwa dimensi konstruk mampu merefleksiakn variable laten.

Tabel 1 Pengujian Validitas Koefisien Bobot Faktor

\begin{tabular}{ccc}
\hline Item & $\begin{array}{c}\text { Standardizaed } \\
\text { Factor Loading }\end{array}$ & Keputusan \\
\hline $\begin{array}{c}\text { Ekuitas Merek } \\
\text { Berbasis Pelanggan }\end{array}$ & 0,835358 & Valid \\
\hline
\end{tabular}

Berdasarkan tabel diatas, diketahui bahwa seluruh dimensi tersebut memiliki nilai loading factor lebih dari 0,5 atau $\lambda>0,5$ sehingga dapat dinyatakan bahwa dimensi tersebut valid atau layak digunakan dalam model strukturak pada penelitian ini.

Tabel 2 Pengujian Validitas Koefisien Bobot Faktor

\begin{tabular}{ccc}
\hline & $\begin{array}{c}\text { Standardizaed } \\
\text { Factor Loading }\end{array}$ & Keputusan \\
\hline $\begin{array}{c}\text { Ekuitas Merek } \\
\text { Berbasis Pelanggan }\end{array}$ & 0,961902 & Reliabel
\end{tabular}

Berdasarkan tabel diatas, diketahui bahwa terdapat seluruh dimensi yang memiliki nilai $\mathrm{R}^{2}$ lebih dari 0,5 atau $\mathrm{R}^{2}>0,5$ sehingga dinyatakan reliabel atau konsisten/handal digunakan dalam model struktural pada penelitian ini.

Selanjutnya yaitu spesifikasi model bagian dari model SEM yang menggambarkan hubungan antara variabel laten dengan indikator-indikatornya. Tahapan ini yang harus dilakukan adalah definisikan variabelvariabel laten yang ada dalam penelitian, yaitu dimensi ekuitas merek berbasis pelanggan diantaranya emotional connection, online experience, responsive service 
nature, Trust, dan Fulfillment. Berikut adalah tabel yang menunjukan hasil perhitungan bobot faktor, regresi, validitas, dan reliabilitas dari masing-masing variabel indikator.

Tabel 3 Pengujian Validitas Koefisien Bobot Faktor

\begin{tabular}{|c|c|c|c|}
\hline & & & Estimate \\
\hline $\begin{array}{l}\text { Emotional } \\
\text { Connection }\end{array}$ & $\leftarrow$ & $\begin{array}{l}\text { Ekuitas Merek } \\
\text { Berbasis } \\
\text { Pelanggan }\end{array}$ & 0,954 \\
\hline $\begin{array}{l}\text { Online } \\
\text { Experience }\end{array}$ & $\leftarrow$ & $\begin{array}{l}\text { Ekuitas Merek } \\
\text { Berbasis } \\
\text { Pelanggan }\end{array}$ & 0,958 \\
\hline $\begin{array}{l}\text { Responsive } \\
\text { Service Nature }\end{array}$ & $\leftarrow$ & $\begin{array}{l}\text { Ekuitas Merek } \\
\text { Berbasis } \\
\text { Pelanggan }\end{array}$ & 0,960 \\
\hline Trust & $\leftarrow$ & $\begin{array}{l}\text { Ekuitas Merek } \\
\text { Berbasis } \\
\text { Pelanggan }\end{array}$ & 0,797 \\
\hline Fulfillment & $\leftarrow$ & $\begin{array}{l}\text { Ekuitas Merek } \\
\text { Berbasis } \\
\text { Pelanggan }\end{array}$ & 0,890 \\
\hline
\end{tabular}

Mengukur variable laten ekuitas merek berbasis pelanggan, online experience merupakan indikator yang paling valid dengan nilai standardized loading estimate 0,958 dan Trust menunjukan validitas paling kecil nilai standardized loading estimate sebesar 0.797. Nilai tertinggi dan terendah dimensi tersebut menunjukan nilai standardized loading estimate $>0.5$ yang menunjukan bahwa dimensi konstruk mampu merefleksiakn variable laten.

Temuan empiris pada penelitian ini menunjukan bahwa ekuitas merek berbasis pelanggan berada pada kategori yang cukup tinggi. Secara berurutan dimensi yang membangun keputusan pembelian adalah emotional connection, online experience, responsive service nature, trust dan Fulfillment. Berdasarkan hasil penelitian yang bersifat empiris mengenai ekuitas merek berbasis pelanggan pada salah satu e-ritel di Indonesia, didapat bahwa dimensi responsive service natures memiliki skor yang paling besar.

\section{KESIMPULAN DAN SARAN}

Gambaran ekuitas merek berbasis pelanggan pada salah satu e-commerce di Indonesia yang diukur berdasarkan emotional connection, online experience,

Copyright ( 92020 BIEJ: Business Innovation \& Entrepreneurship Journal e-ISSN : 2684-8945 responsie service nature, trust dan fulfillment berada pada kategori cukup tinggi. Artinya penilaian ekuitas merek berbasis pelanggan secara keseluruhan berada pada kategori cukup tinggi sehingga dinilai cukup baik. Dimensi responsive service nature secara keseluruhan memiliki nilai paling tinggi, sedangkan untuk dimensi yang memiliki nilai terendah adalah trust.

Ada beberapa yang menjadi batasan dan pertimbangan pada penelitian ini yang dapat menjadi rujukan bagi peneliti selanjutnya. Pertama, penelitian ini dilakukan hanya pada satu waktu, desain longitudinal dapat digunakan untuk memetakan aspek temporal dan memberikan dukungan empiris yang lebih ketat untuk teori tersebut. Kedua, kami menyadari fakta bahwa focus hanya pada satu industrI yang membatasi generalisasi hasil kami. Pada saat yang sama, ini memungkinkan kontrol penting dan meningkatkan validitas internal hasil. Penelitian selanjutnya mungkin ingin memvalidasi pada industry yang berbeda. Ketiga, penelitian ini dibatasi oleh konstruk yang dipelajari. Studi di masa depan dapat mempelajari efek dan interaksi tingkat merek lainnya untuk menjelaskan kondisi batas potensial. Namun demikian, penelitian selanjutnya diharapkan dapat mengurangi bias yang ada pada penelitian ini.

\section{REFERENSI}

[1] Bill, J., Andrew, X., Xu, J. B., \& Chan, A. (2010). A Conceptual Framework of Hotel Experience and Customer-Based Brand Equity Some Research Questions and Implications. International Journal of Contemporary Hospitality Management, 22(2), 174-193. https://doi.org/10.1108/09596111011018179

[2] Blumrodt, J., Bryson, D., Flanagan, J., Blumrodt, J., Bryson, D., \& Flanagan, J. (2013). European Football Teams ' CSR Engagement Impacts on Customer-Based Brand Equity. Journal of Consumer Marketing, 29/7, 482-493. https://doi.org/10.1108/07363761211274992

[3] Christodoulides, G., Cadogan, J. W., Veloutsou, C., \& Christodoulides, G. (2015). Consumerbased brand equity measurement : lessons learned from an international study, 32(3/4), 307-328. http://doi.org/10.1108/IMR-10-2013-0242 
[4] Christodoulides, G., Chernatony, L. De, Furrer, O., \& Shiu, E. (2006). Conceptualising and Measuring the Equity of Online Brands. Journal of Marketing Management, 22(7-8), 799-825. https://doi.org/10.1362/026725706778612149

[5] Emari, H. (2012). Determinants of Brand Equity: Offering a Model to Chocolate Industry in Iran. l(1), 14-23.

[6] Farjam, S., \& Hongyi, X. (2015). Reviewing the Concept of Brand Equity and Evaluating Consumer-Based Brand Equity ( CBBE ) Models Brand Equity Perspectives Financial perspective. 1(8), 14-29.

[7] Fouladivanda, F., Pashandi, M. A., \& Hooman, A. (2013). The effect of Brand Equity on Consumer Buying Behavior in term of FMCG in Iran. Institute of Interdisciplinary Business Research, 4, 945-957.

[8] Grant, D. (2014). Investigating Brand Equity of Third-Party Service Providers. Journal of Services Marketing,

124-222. https://doi.org/10.1108/JSM-06-2012-0104

[9] Hakala, U., Svensson, J., Vincze, Z., Hakala, U., \& Svensson, J. (2012). Consumer-based brand equity and top-of-mind awareness: a crosscountry analysis. https://doi.org/10.1108/10610421211264928

[10] Kavoura, A. (2014). Social Media , Online Imagined Communities and Communication. 63, 490-504. https://doi.org/10.1108/LR-06-20140076

[11] Keller, K. L. (2013). Strategic Brand Management (Fourth Edi). Pearson Education, Inc.

[12] Keller, K. L. (2016). Marketing Management. Pearson Education Limited.

[13] Keller, K. L., Chernatony, L. De, \& Muniz, A. M. (2009). Brand Management. Routledge.

[14] Kim, J., Sharma, S., \& Setzekorn, K. (2002). A Framework for Building Brand Equity Online for Pure-Play B2C Retailers and Services to JMM. $4(2), 123-132$.

Copyright (C) 2020 BIEJ: Business Innovation \& Entrepreneurship Journal e-ISSN : 2684-8945
[15] Kristal, S., Baumgarth, C., Behnke, C., \& Henseler, J. (2016). Is Co-creation Really a Booster for Brand Equity? The Role of Cocreation in Observer-Based Brand Equity (OBBE ). https://doi.org/10.1108/JPBM-05-2015-0893

[16] Lieven, T., \& Hildebrand, C. (2016). The Impact of Brand Gender on Brand Equity Findings from a Large-Scale. https://doi.org/10.1108/IMR-082014-0276

[17] Liu, C.-C. S. and D.-J. (2015). Correlation Between the Homestay Experience and Brand Equity Using the Yuehetang Rural Residence as a. Journal of Hospitality and Tourism Technology, Vol.6 No.I, 59-72. https://doi.org/10.1108/JHTT01-2015-0008

[18] Lu'ay Al-Mu'ani. (2015). International Journal of Online Marketing Research The Effect of Marketing Communications on Customer Based Brand Equity. 1(1), 13-25.

[19] Marcelo, P., Mário, T., Augusto, G., Veríssimo, J., Torres, P. M., \& Augusto, M. G. (2015). Determining The Causal Relationships That Affect Consumer-Based Brand Equity The Mediating Effect of Brand Loyalty. https://doi.org/10.1108/MIP-11-2014-0211

[20] Pappu, R., Quester, P. G., Cooksey, R. W., Pappu, R., \& Cooksey, R. W. (2006). Evidence Consumer-Based Brand Equity and Country-ofOrigin Some Empirical Evidence. European Journal of Marketing, 40 No.5/6, 696-717. https://doi.org/10.1108/03090560610657903

[21] Pinar, M. (2016). Services Branding Triangle Examining the Triadic Service Brand Promises. International Journal of Bank Marketing, Vol. 34 No, 529-549. https://doi.org/10.1108/IJBM-042015-0043

[22] Schivinski, B., \& Dabrowski, D. (2015). The Impact of Brand Communication on Brand Equity Through Facebook. 9 No.I, 31-53. https://doi.org/10.1108/JRIM-02-2014-0007

[23] Sekaran, U. (2006). Metodologi Penelitian untuk Bisnis. In 2. Salemba Empat. 
[24] Simmons, G. (2010). Managing i-Branding to Create Brand Equity. European Journal of Marketing, 44 No.9, 1290-1285. https://doi.org/10.1108/03090561011062835

[25] Su, J. (2016). Examining the relationships among the brand equity dimensions Empirical evidence from fast fashion. Asia Pacific Journal of Marketing and Logistics, 28(3), 464v-480. http://doi.org/10.1108/APJML-01-2015-0004

[26] Tabachnick, B. G. and L. S. F. (2013). Using Multivariate Statistics, Sixth Edition. Boston: Pearson Education, Inc.

[27] Tong, X., Hawley, J. M., \& Hawley, J. M. (2014). Measuring customer-based brand equity: empirical evidence from the sportswear market in China, 18(4), 262-271. http://doi.org/10.1108/10610420910972783

[28] Veloutsou, C., Christodoulides, G., Chernatony, L. De, \& Veloutsou, C. (2013). A taxonomy of measures for consumer-based brand equity: drawing on the views of managers in Europe. Journal of Product \& Brand Management, 22(3), 238-248. https://doi.org/10.1108/JPBM-02-20130256

[29] Yazdanparast, A., Joseph, M., Muniz, F., Yazdanparast, A., Joseph, M., \& Muniz, F. (2016). Consumer Based Brand Equity in the 21st Century: an Examination of the Role of Social Media Marketing. Vol 17 No., 243-355. https://doi.org/10.1108/YC-03-2016-00590

[30] Zhu, J. Z. Y. J. R. S. M. (2016). How Brand Orientation Impacts B2B Service Brand Equity? An Empirical Study Among. 31, 83-89. https://doi.org/10.1108/JBIM-02-2014-0041

\section{Website}

[31] Randi Eka. 2016 "Pertumbuhan Industri Startup Indonesia Diperkirakan Mencapai 6,5 Lipat di Tahun 2020”. https://dailysocial.id/ 